\title{
Whitening of a Non-Vital Tooth with Walking Bleach Technique: A Case Series
}

\section{DEEPIKA*1, MUHAMMAD MUTIUR RAHMAN², AJAY KUMAR NAGPAL}

A significant aspect of cosmetic dentistry is the treatment of tooth discoloration. Discoloration of non-vital anterior teeth can cause significant esthetic concern and requires efficient treatment. Discoloration of teeth can be extrinsic or intrinsic or a combination of both based on etiology, appearance, localization, and severity. Walking bleach involves the use of chemical substances like sodium perborate or hydrogen peroxide which in contact with the tooth release oxidizing agents that diffuse through the enamel and dentin and oxidize the pigments responsible for discoloration. This article aims at presenting a case series on the walking bleach method performed on discolored endodontically treated teeth associated with superior esthetic outcomes.

KEYWORDS: Hydrogen Peroxide, Teeth, Endodontics

\section{INTRODUCTION}

Increased cases of tooth whitening have been noted in dental practice over the last decade, with a greater preference for minimally invasive procedures. Several methods have been developed with the goal of treating non-vital tooth discoloration. Full veneer crowns are traditionally preferred to restore aesthetics in endodontically treated anterior teeth. In case with a sound tooth structure and mild to moderate discoloration, bleaching is a favourable option. It is also non-invasive, less time-consuming and cost-effective. ${ }^{-1}$ 4

Walking bleach technique employs the use of chemicals that release active oxygen i.e. hydrogen peroxide $\left(\mathrm{H}_{2} \mathrm{O}_{2}\right)$ or sodium perborate (SP). Very often combination of SP and water or $\mathrm{H}_{2} \mathrm{O}_{2}$ are being used in the "walking bleach" technique..$^{5-6}$ The effect of bleaching depends on the factors such as firstly the concentration of the bleaching agent, second the ability of the agent to enter the chromophore molecules and lastly the length and amount of time the agent is in contact with chromophore molecules. ${ }^{7}$

Intrinsic discoloration may be caused by systemic or local causes. The systemic explanations include metabolic fluorosis linked to drugs (tetracycline), and hereditary (hyperbilirubinemia, amelogenesis imperfecta, and dentinogenesis imperfecta),${ }^{8}$ whereas the local reasons include necrosis of pulp, intrapulpal hemorrhage, remnants of pulp tissue after endodontic therapy, endodontic root canal materials, coronal filling materials, root resorption, and aging. ${ }^{9}$ The present case series reports successful bleaching accomplished in the discolored nonvital anterior endodontically treated tooth. Two different approaches of walking bleach technique was performed.

\section{CASE 1}

A 24-year-old young female patient reported to the Department of Conservative Dentistry and Endodontics with a chief complaint of discolored upper front tooth and wanted to get whitening of the discolored tooth. Patient had a history of trauma with respect to upper front teeth eight years back. On examination, maxillary left central incisor tooth was discolored and structurally intact and firm (figure 1). An intraoral radiograph showed widening of periodontal ligament space and discontinuity in lamina dura and mild radiolucency in periapical region with 21 (figure 2). Patient was explained about the root canal therapy followed by intracoronal bleaching for the tooth and informed consent was taken. B2 shade was determined using VITA shade guide and preoperative photographs were taken. Root canal therapy was performed under the proper isolation. The preparation in the pulp chamber for bleaching was done by removing $2 \mathrm{~mm}$ of gutta-percha near orifice (figure 3) 


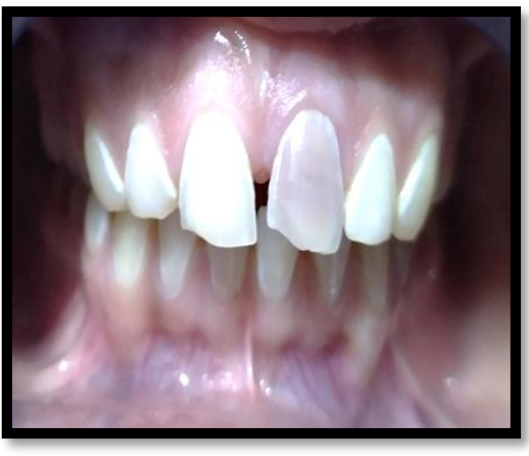

Figure 1. Preoperative photograph

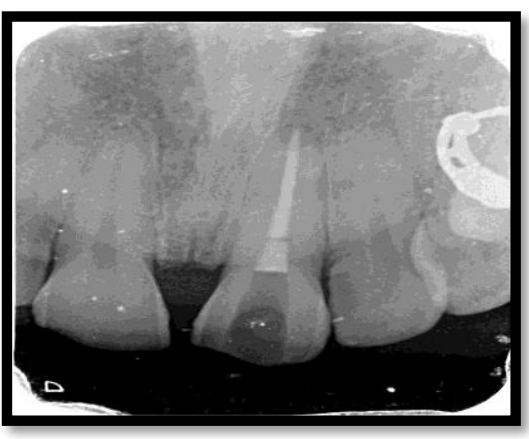

Figure 4. GIC placed at level of CEJ

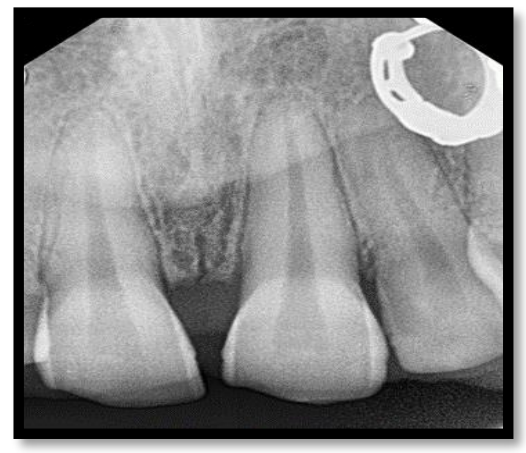

Figure 2. Preoperative radiograph

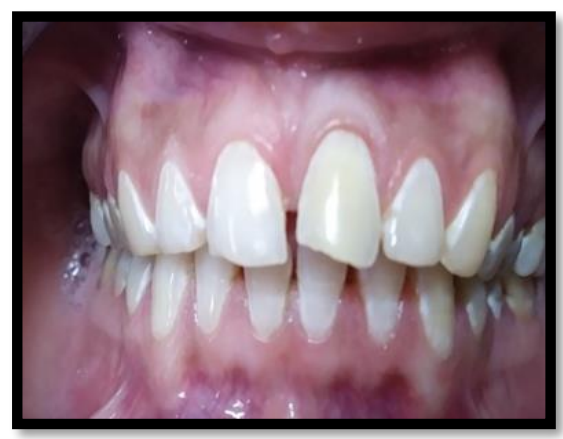

Figure 5. Follow up after one week

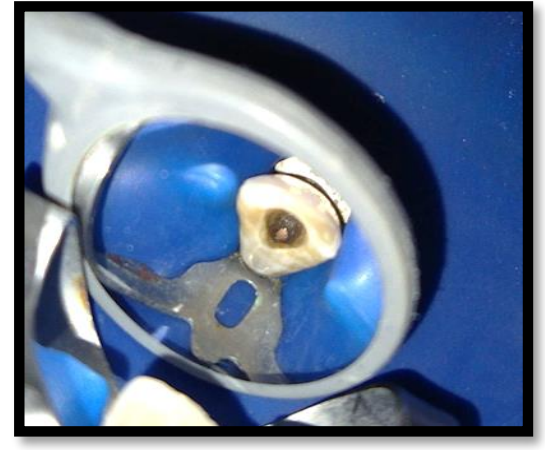

Figure 3. Intracoronal chamber

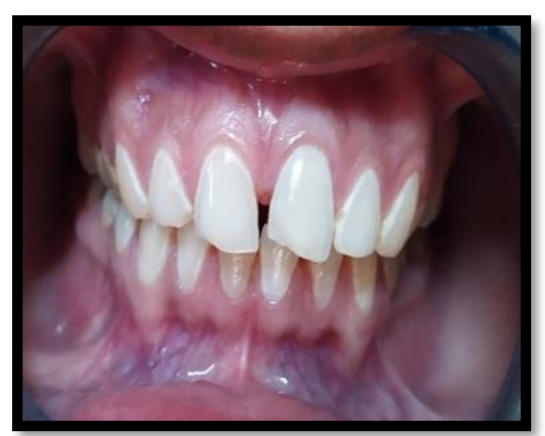

Figure 6. Post-operative photograph and 1 to $2 \mathrm{~mm}$ glass ionomer cement (GIC) (Ivoclar Vivadent) was placed over it to create a mechanical barrier between the root canal at the level of cemento enamel junction (figure 4). Bleaching agent was placed inside pulp chamber using applicator tip then cavity was sealed by using zinc phosphate (ShofuHy-Bond Zinc Phosphate Cement) as temporary restoration. Bleaching was carried out using a paste of sodium perborate prepared by mixing with distilled water. In this case, the same procedure was repeated every 1 week in two-time interval (figure 5). After two weeks, the anticipated results were achieved with better cosmetic appearance, even the shade got lighter to A1 (figure 6). Following this, the tooth was then permanently restored using composite resin (3M EspeFiltek Z250 Xt).

\section{CASE 2}

A 19 years old young adult was referred to the Department of Conservative Dentistry and Endodontics for treatment of discolored maxillary right central incisor teeth (figure 7). History of dental trauma in the same region dated back to 6 years. The preoperative radiograph showed the extent of fracture to the pulp chamber with periapical radiolucency. Patient was explained in detail about the root canal therapy and intracoronal bleaching for the same tooth. Informed consent was taken prior to commencement of the root canal treatment done in relation to 11 and 12 . Preoperatively, VITA Classical shade guide was used to determine and match the tooth color under normal daylight. A 3.5 shade was determined using VITA shade guide. Gutta-percha was removed just below the cemento enamel junction. The glass ionomer cement (GIC) (Ivoclar Vivadent) barrier of $2 \mathrm{~mm}$ thickness was applied (figure 8). Bleaching was carried out using a paste of sodium perborate prepared by mixing with $10 \%$ carbamide peroxide. Using applicator tip, Bleaching agent was placed inside pulp chamber (figure 9). The tooth was coronally then sealed with the help of zinc phosphate (ShofuHy-Bond Zinc Phosphate Cement). The tooth showed significant changes in shade after 7 


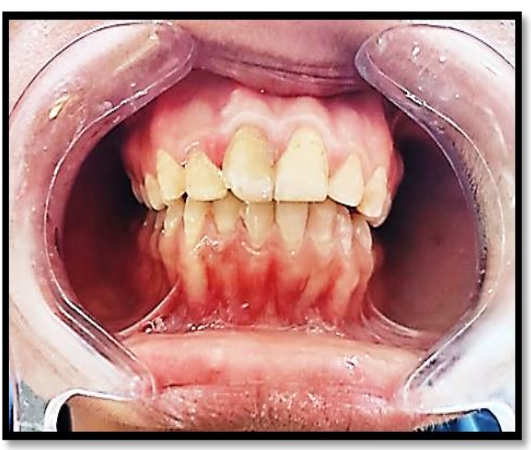

Figure 7. Preoperative photograph

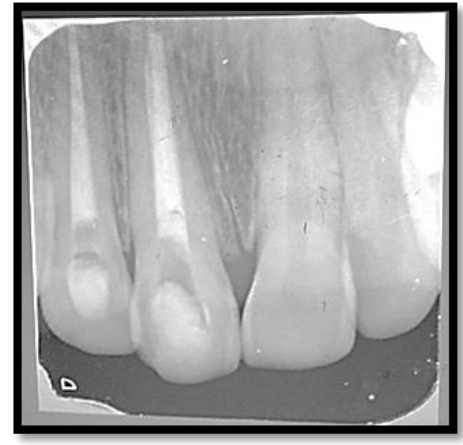

Figure 8. Radiograph after placing GIC barrier

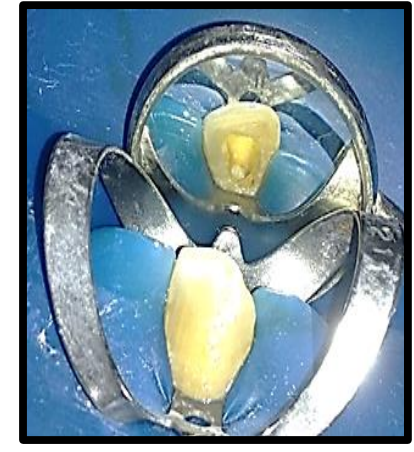

Figure 9. After placing bleaching agent days. The shade changed to $\mathrm{A}_{2}$ from $\mathrm{A}_{3.5}$ (figure 10). The tooth was then permanently restored using composite resin (3M EspeFiltek Z250 Xt).

\section{DISCUSSION}

Intrinsic discoloration occurs due to entrapment of chromogenic content within enamel or dentin, either during tooth formation or after eruption, whereas extrinsic discolorations occurs on the surface. ${ }^{7}$ Intrinsic stains are classified as pre-eruptive and post-eruptive stains. 9 Pre-eruptive discoloration may result from exposure to elevated fluoride levels, tetracycline administration, hereditary developmental anomalies, and damage to the developing tooth. Aging, pulp necrosis, and iatrogenesis are the primary sources of intrinsic discoloration following the tooth eruption. Extrinsic stains originate from chocolate, tea, red wine, carrots, grapes, and cigarettes. A thorough and definitive understanding of the etiology of teeth discoloration is crucial for arriving at a correct diagnosis and formulating appropriate treatment plan. $^{10}$

Numerous options are available for the treatment of discolored endodontically treated anterior teeth: full veneers, laminates, crowns, and non-invasive procedure such as bleaching. ${ }^{11}$ Traditionally, laminate, veneer or a complete porcelain crown are treatment options in these situations but they involve removal of substantial amount of the tooth structure..$^{12,13}$

In the mid-19 ${ }^{\text {th }}$ century, bleaching of discolored non vital teeth using lime chloride was first reported. At first, the bleaching effect of $\mathrm{H}_{2} \mathrm{O}_{2}$ on the tooth was discovered in 1884 and before this various bleaching agent like aluminum chloride and oxalic acid were identified. ${ }^{14,15}$

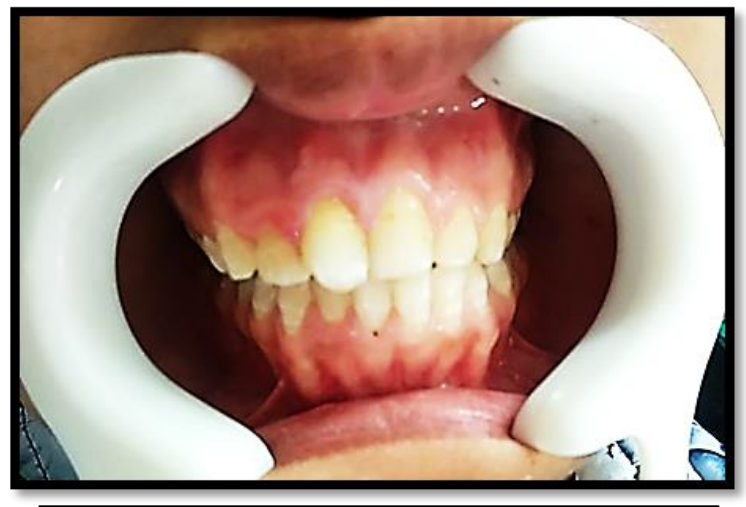

Figure 10. Post-operative photograph

For the very first time, Spasser described Walking bleach method. This method uses sodium perborate (SP) mixed with distilled water. ${ }^{16}$ Sodium perborate serves as an oxidizing agent containing $95 \%$ perborate that exists in the form of mono, tri $\left(\mathrm{NaBO}_{2} \cdot \mathrm{H}_{2} \mathrm{O}_{2}\right.$ ${ }_{3} \mathrm{H}_{2} \mathrm{O}$ ) or tetra hydrate. ${ }^{17}$ Sodium perborate when combined with water releases $\mathrm{H}_{2} \mathrm{O}_{2}{ }^{16}$ Nutting and Poe later modified this method by replacing $\mathrm{H}_{2} \mathrm{O}$ with $30 \%$ $\mathrm{H}_{2} \mathrm{O}_{2}$ to improve the effect. ${ }^{18}$ The use of a bleaching agent with a high $\mathrm{H}_{2} \mathrm{O}_{2}$ concentration in combination with heating tends to encourage resorption of the cervical root. ${ }^{19,20}$ The leakage of bleaching agent through dentinal tubules initiates an inflammatory reaction. ${ }^{21}$ The SP releases active oxygen radicals inside the pulp chamber, which diffuses into the dentinal tubules. ${ }^{22}$ The iron sulfide and other pigments present in the dentinal tubules get oxidized and bleached, and 
also the free radicals induce oxidative effects on lipids, proteins and nucleic acids. ${ }^{23,24}$

Resorption of the cervical root is a major concern while performing nonvital tooth bleaching. Studies have demonstrated that the use of SP and water mixture have a low potential to induce cervical resorption. To avoid leaching of bleaching agent, glass ionomer cement was placed as a sealant barrier. ${ }^{20,25}$ This also prevents the diffusion of hydrogen peroxide in the surrounding extra-radicular environment. ${ }^{26}$ When a combination of sodium perborate-tetrahydrate and water is used, the amount of hydrogen peroxide diffusion is significantly less compared with the use of $30 \%$ hydrogen peroxide combined with different sodium perborates. ${ }^{27}$

Carbamide peroxide $\left(\mathrm{CH}_{4} \mathrm{~N}_{2} \mathrm{O} \cdot \mathrm{H}_{2} \mathrm{O}_{2}\right)$ is an organic compound comprising of $\mathrm{H}_{2} \mathrm{O}_{2}$ and urea products. $10 \%$ carbamide peroxide releases $3.5 \%$ hydrogen on decomposition. ${ }^{28,29}$ Evidence is also available from the in vitro studies which mention that SP in water, SP in $\mathrm{H}_{2} \mathrm{O}_{2}$ (both $3 \%$ and $30 \%$ ), and $10 \%$ carbamide peroxide are effective agents for the internal bleaching of nonvital teeth..$^{0}$

In this case series, the walking bleach method was performed by applying a thick paste of sodium perborate mixed with distilled water and alternatively with $10 \%$ carbamide peroxide on the desired site in the pulp chamber for a period of 7 days and the patient was recalled periodically for evaluation. The whole procedure was repeated till the desired result was obtained.

\section{CONCLUSION}

The present case series highlights the efficiency of the nonvital bleaching method where, sodium perborate is used with distilled water and alternatively with $10 \%$ carbamide peroxide to attain successful and predictable cosmetic results. No signs of relapse of discoloration or cervical root resorption were seen at follow up in both the cases. Henceforth, it can be summarized that walking bleach method can be considered as a potential treatment of choice for discolored nonvital endodontically treated teeth.

\section{REFERENCES}

1. Ingle JI, Beveridge EE. Endodontics. $2^{\text {nd }}$ edition. Philadelphia (PA): Lea and Febiger; 1976.

2. Cohen SC. Bums RC. Pathways of the pulp. St. Louis (MO): C.V. Mosby; 1980.
3. MacIsaac AM, Hoen CM. Intracoronal bleaching: concerns and considerations. J Can Dent Assoc. 1994; 6o:57-64.

4. Rostein, I. Tooth discoloration and bleaching. In: Ingle JI, Bakland LK, editors. Endodontics. $5^{\text {th }}$ ed. Hamilton: BC Decker Inc.; 2002: 845-86o.

5. Camps J, de Franceschi H, Idir F, Roland C, About I. Time course diffusion of hydrogen peroxide through human dentin: Clinical significance for young tooth internal bleaching. J Endod. 2007; 33:455-9. https://doi.org/10.1016/j.joen.2006.12.0o6.

6. Holmstrup G, Palm AM, Lambjerg Hansen H. Bleaching of discoloured root-filled teeth. Endod Dent Traumatol. 1988; 4:197-201. https://doi.org/10.1111/j.16oo-9657.1988.tboo322.x.

7. Dahl JE, Pallesen U. Tooth bleaching - A critical review of the biological aspects. Crit Rev Oral Biol Med. 2003; 14:292 304. https://doi.org/10.1177/154411130301400406.

8. Ambalia SV, Ramgadhia HS. Nonvital tooth bleaching, noninvasive technique: a case report. IOSR J Dent Med Sci 2017; 16:80-82. https://doi.org/10.979o/o853-1603088082

9. Nathoo SA. The chemistry and mechanism of extrinsic and intrinsic discoloration. J Am Dent Assoc. 1997; 128:6S-10S. https://doi.org/10.14219/jada.archive.1997.0428.

10. Watts A, Addy M. Tooth discolouration and staining: a review of the literature. Br Dent J. 2001; 190:309-16. https://doi.org/10.1038/sj.bdj.4800959

11. Fearon J. Tooth whitening: Concepts and controversies. J Ir Dent Assoc. 2007; 53:132-40.

12. Beier US, Kapferer I, Burtscher D, Dumfahrt H. Clinical performance of porcelain laminate veneers for up to 20 years. Int J Prosthodont 2012; 25:7-85.

13. Chen YW, Raigrodski AJ. A conservative approach for treating young adult patients with porcelain laminate veneers. J Esthet Restor Dent 2008; 20:223-36. https://doi.org/10.1111/j.1708-8240.2008.00184.x.

14. Fasanaro TS. Bleaching teeth: history, chemicals and methods used for common tooth discolorations. J Esthet Dent 1992; 4:71-8. https://doi.org/10.1111/j.17088240.1992.tboo666.x.

15. Goldstein RE. In-office bleaching: where we came from, where we are today. J Am Dent Assoc. 1997; 128:11S-15S.

https://doi.org/10.14219/jada.archive.1997.0415.

16. Spasser HF. A simple bleaching technique using sodium perborate. N Y State Dent J. 1961; 27:332-334. 17. Rotstein I, Mor C, Friedmann S: Prognosis of intracoronal bleaching with sodium perborate preparations in vitro: 1-year study. J Endod. 1993; 19:102. https://doi.org/10.1016/soo99-2399(06)81033-2. 
18. Nutting EB, Poe GS. Chemical bleaching of discolored endodontically treated teeth. Dent Clin

North Am. 1967; 11:655-62.

19. Baratieri LN, Ritter AV, Monteiro S Jr., Caldeira de Andrada MA, Cardoso Vieira LC. Nonvital tooth bleaching: Guidelines for the clinician. Quintessence Int. 1995; 26:597-608.

20. Friedman S, Rotstein I, Libfeld H, Stabholz A, Heling I. Incidence of external root resorption and esthetic results in 58 bleached pulpless teeth. Endod Dent Traumatol. 1988; 4:23-6. https://doi.org/10.1111/j.160o-9657.1988.tboo288.x.

21. Cvek M, Lindvall AM. External root resorption following bleaching of pulp less teeth with oxygen peroxide. Endod Dent Traumatol. 1985;1:56-6o. https://doi.org/10.1111/j.16oo-9657.1985.tboo561.x.

22. Kawamoto K, Tsujimoto Y. Effects of the hydroxyl radical and hydrogen peroxide on tooth bleaching. J Endod. 2004; 30:45-50. https://doi.org/10.1097/oooo4770-200401000-00010. 23. Attin T, Paqué F, Ajam F, Lennon AM. Review of the current status of tooth whitening with the walking bleach technique. Int Endod J. 2003; 36:313-29. https://doi.org/10.1046/j.1365-2591.2003.00667.x.

24. Plotino G, Buono L, Grande NM, Pameijer $\mathrm{CH}$, Somma F. Nonvital tooth bleaching: A review of the literature and clinical procedures. J Endod. 2008; 34:394-407. https://doi.org/ 10.1016/j.joen.2007.12.020.
25. Ari $\mathrm{H}$, Ungör M. In vitro comparison of different types of sodium perborate used for intracoronal bleaching of discolored teeth. Int Endod J. 2002; 35:433-6. https://doi.org/10.1046/j.13652591.2002.00497.x.

26. Rotstein I, Zyskind D, Lewinstein I, Bamberger N. Effect of different protective base materials on hydrogen peroxide leakage during intracoronal bleaching in vitro. J Endod. 1992; 18:114-7. https://doi.org/10.1016/Soo99-2399(o6)81310-5.

27. Weiger R, Kuhn A, Lost C. Radicular penetration of hydrogen peroxide during intra-coronal bleaching with various forms of sodium perborate. Int Endod J. 1994; 27:313-7. https://doi.org/10.1111/j.13652591.1994.tboo275.x.

28. Goldstein GR, Kiremidjian-Schumacher L. Bleaching: is it safe and effective? J Prosthet Dent. 1993; 69:325-8. https://doi.org/10.1016/0022-3913(93)90114-4. 29. Féliz-Matos L, Hernández LM, Abreu N. Dental Bleaching Techniques; Hydrogen-carbamide Peroxides and Light Sources for Activation, an Update. Mini Review Article. Open Dent J. 2015; 8:264-8. https://doi.org/10.2174/1874210601408010264

30. Almohareb T. Management of discoloured endodontically treated tooth using sodium perborate. J Int Oral Health. 2017; 9:133-5. https://doi.org/10.4103/jioh.jioh_131_17

Cite this article as:

Deepika, Rahman MM, Nagpal AK. Whitening of a Non-Vital Tooth with Walking Bleach Technique: A Case Series. Int Healthc Res J. 2021;5(2):CR1-CR5. https://doi.org/10.26440/IHRJ/0502.05415

AUTHOR AFFILIATIONS: $\left({ }^{*}\right.$ Corresponding Author)

1. Post Graduate Student

2. Senior Lecturer

3. Professor and Head

Department of Conservative Dentistry and Endodontics, K. D. Dental College \& Hospital, Mathura, India. 